\title{
A Journey of Goods and Services Tax (GST) and Structural Impact of GST on the Growth of GDP in India
}

\author{
Kankipati Ajay Kumar \\ Department of Management, Pace Institute of Technology and Sciences, Ongole, India \\ Email address: \\ ajaykumarkankipati@gmail.com \\ To cite this article: \\ Kankipati Ajay Kumar. A Journey of Goods and Services Tax (GST) and Structural Impact of GST on the Growth of GDP in India. \\ Advances in Sciences and Humanities. Vol. 3, No. 5, 2017, pp. 50-53. doi: 10.11648/j.ash.20170305.12
}

Received: June 3, 2017; Accepted: June 16, 2017; Published: October 18, 2017

\begin{abstract}
In Developing countries like India, the taxation system is very crucial role in the development of revenues of the country. But India tax system is difficult to understand and in fact for calculation too in case of both direct tax as well as indirect tax. In order to overcome the problems of the government of India tries to simply the direct tax as well as indirect tax, the government made the proposal of introducing GST (goods and services tax) instead of all indirect taxes and DTC (direct tax code) instead of direct tax. But fortunately GST won the first place in the purview of implementation. The government of India is committed to replace all the indirect taxes levied on the services and goods by state and central government in the month of April 2017. This paper made an attempt to explain the level of impact of this GST (goods and services tax) on the growth of the economy, and benefits for the business and government and for the consumers.
\end{abstract}

Keywords: Direct Tax Code, Goods and Services Tax, Gross Domestic Product, Indirect Tax, Impact of GST

\section{Introduction}

As per Article of 366 of the 122nd Constitutional Amendment Bill, 2014 [Constitution (101st Amendment) Act, 2016] "Goods and Services Tax means any tax on supply of goods, or services or both except taxes on the supply of the alcoholic liquor for human consumption". Internationally Goods and Services Tax (GST) is popularly known as VAT [10]. In 1954, France adopted GST as its indirect taxation structure and became the first country to adopt the GST. Within 62 years of its start, about 164 countries across the world have adopted GST because this taxation system has the capacity to raise revenue in the most transparent and unbiased manner. Most of the countries follow unified GST i.e., a single tax applicable throughout the country. However, in national politics like Brazil and Canada, a dual GST system is prevalent. Under dual system, GST is levied by both the national and the state governments. India, also intends to adopt a dual GST [7] [8] [4] [10].

Internationally Goods and Services Tax (GST) is regularly called as VAT. In 1954, France adopted GST as its indirect tax structure, became the first country to adopt GST [2]. Since 62 years of its start, more than 164 countries across the world have adopted GST because this taxation system has its capacity to raise revenue in the most transparent and large extent level. Many of these countries follow same type of GST i.e., a single tax applicable throughout the country [6]. At the same time, in national politics like Brazil and Canada, a dual GST system [4]. Under dual system, GST is levied by both the national and the state governments. India, also intends to adopt a dual GST [4] [6] [8].

\subsection{Goods and Services Tax}

Goods - "Goods" means every kind of movable property other than actionable claim and money but includes securities, growing crops, grass and things attached to or forming part of the land which are agreed to be severed before supply or under the contract of supply.

\subsection{Services - Meaning}

Services - "Services" means anything other than goods. Services include intangible property and actionable claim but do not include money. Further, Section 3of Draft CGST/SGST Act, 2016 provides the meaning of the term "supply".

Supply - All forms of supply of goods and/or services such as sale, transfer, barter, exchange, license, rental, lease or 
disposal made or agreed to be made for a consideration by a person in the course or furtherance of business.

\section{The Journey of Goods and Services Tax}

In case of GST there's a single tax at the same time continuous chain of tax credits from the manufacturer to the major consumer. The supplier/initiator at each stage can avail the input credit of GST paid on the purchase of goods and services and can set off or adjust this credit against the GST payable on the supply of goods and services to be made opted by him. Thus, only the ultimate consumers bear that GST burden charged by the last supplier in supply chain, with setoff or adjust benefits at all the previous stages. [6] [8] [10] Hence, only the value added at each stage is taxed under GST and there is no tax on tax under GST system. In GST the goods and services are not at all Differentiated and, the goods and services are taxed a single rate [7] [9].

In the year of 2003 the concept of Goods and Services Tax (GST) was introduced by the Kelkar Task Force. This Task Force strongly recommended the implementation of this GST on nation basis. By this Afterward, then Union Finance Minister, Shri P. Chidambaram, during Central Budget (2006-2007), has announced that GST would be introduced from April 1, 2010. But In 2007, study paper on GST authored by Dr. Parthasarathy shome was released. This 13th finance commission releases its report on GST in the month of December, 2009. [3] [6] [9] Wholly In August, 2013 the standing committee on finance tabled its report on the Bill of GST. On 19th December, 2014, 122nd Constitutional Amendment Bill, 2014 was introduced in the Lok Sabha by the Union Government. It was drafted by keeping in mind the earlier developments as well as suggestions made by the Standing Committee on area of Finance and the pending demands of State level Finance Ministers [2] [4] [9].

At the time of March, 2016 the Finance Minister that is Arun Jaitley says he agrees with the Congress's demand that the GST rate must not more than (18\%) followed After that, the Bill was passed in Lok Sabha on the Date 6th May, 2015 and it was referred a Select Committee of Rajya Sabha on $14^{\text {th }}$ May, 2015. Very recently, on 3rd of August, 2016 the much awaited Bill was passed in the Rajya Sabha as well afterwards. [3] With this passage of $122^{\text {nd }}$ Constitutional Amendment Bill, that 2014 for the introduction of GST in two houses of the Parliament, and got approval of The President of India and now the Government is clear in its intention made of implementing GST by April, 2017. however, the Draft Model GST law was placed on public portal by Government of India on 14th June, 2016 inviting various comments and suggestions for the consideration for any Modifications.

\section{Objectives of the Study}

(a) To know the features of GST bill (b) To understand the benefits that the economy will going to have.

(c) To get an idea of level of success in the area of implementation.

(d) To know history of goods and services tax as well.

\section{Research Methodology}

This is a conceptual framework research; the entire source of collection of data is secondary that includes government websites, various journals and articles, publications and conference papers too.

\subsection{Dual System - Goods Services Tax}

India intends to follow a dual model of GST that will be imposed concurrently by the States and central as well. The dual model was propounded in the First Discussion which was released by the Empowered Committee with an objective to go away from the problem of tax on tax that is called double taxation and to move to a common tax base and also to have various Central and State levies on goods and services into Central Goods and Services Tax (CGST) and State Goods and Services Tax (SGST) [8] [11].

(1) Central GST, collected by the Central Govt - CGST

(2) State GST, collected by the State Govt- SGST.

(3) Integrated GST, collected by the Central Govt - IGST

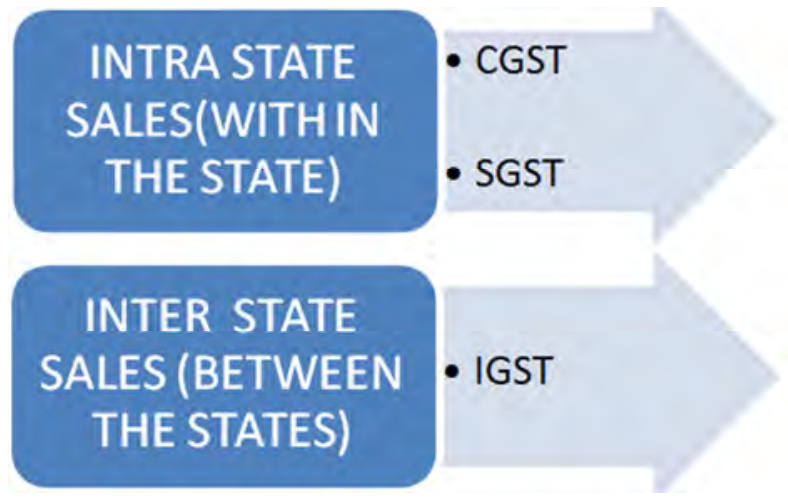

Figure 1. Framework of Dual system of GST in India 2017.

\subsubsection{Intra State Tax [CGST \& SGST]}

GST is a destination based tax applicable on all the transactions which involves supply of goods and services for a consideration. GST will have a dual rate structure of comprising CGST, which will be levied as well as collected by Central Government, and SGST, which will be levied and collected by State Governments [4] [6].

All local and all intra-State supplies of taxable goods and services will be liable to both CGST \& SGST except when the same get excluded on account of turnover threshold limits or other exemptions. To the Credit of CGST and SGST will be available throughout the supply chain but cross utilization of credit of CGST and SGST will not be possible. Since from the time of introduction of GST will be a destination based tax, revenue of SGST will ordinarily accrue to the consuming States [2] [7]. 
Ex: if Mr. X produced the good and sold to $\mathrm{Y}$, this $\mathrm{Y}$ sold to $\mathrm{Z}$, here $\mathrm{Y}, \mathrm{Z}$ belongs to within the state, then it is considered as intra sales transaction. Hence it is comes under CGST and SGST.

\subsubsection{Inter State Tax [IGST]}

An Integrated Goods and Service Tax (IGST) model will be used for the taxation of inter-State supply of goods and services. IGST would be approximately a sum total of CGST and SGST. Under this model, IGST will be levied by Centre on all inter-State supplies of taxable goods and services. The inter-State supplier in the exporting State will be allowed to set off the available credit of IGST, CGST and SGST (in that order) against the IGST payable on inter-State supply made by him. The buyer in the importing State will be allowed to avail the credit of IGST paid on inter- State purchase made by him [3] [7] [9].

Since GST will be a destination based tax, the revenue of inter-State sale will not accrue to the exporting State and the exporting State will be required to transfer to the Centre the credit of SGST used in payment of IGST. The Centre will transfer to the importing State the credit of IGST used in payment of SGST. There will be a Central Agency to act as a clearing house and verify the claims and inform the respective Governments to transfer the funds. Successful execution of IGST model would require robust and efficient IT infrastructure [4] [8] [10].

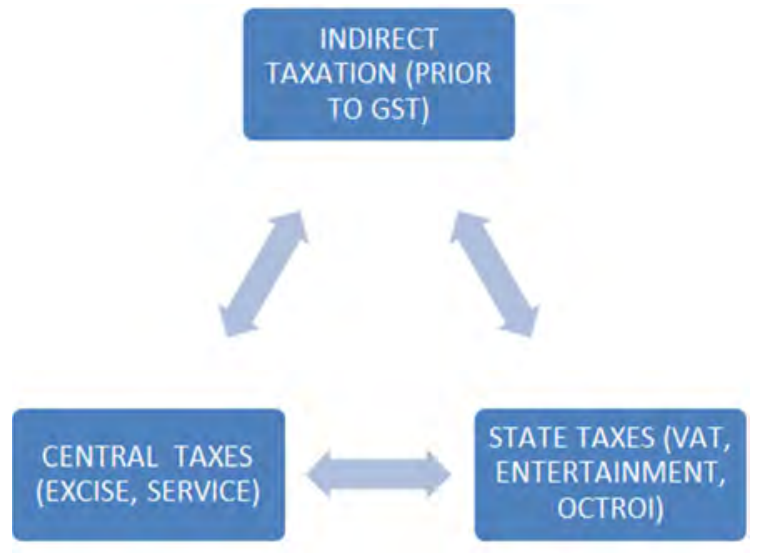

Figure 2. Framework of Integrated GST.

Paid by Manufacture, Wholesaler, Retailers \& final Consumer

\subsection{Indirect Taxation Structure Which will Get in Goods Services Tax}

\subsubsection{Central Taxes Which will Get Subsumed in GST}

The following taxes Ruined with introduction of GST, those are

(1) Service Tax and Central Excise Duty

(2) Excise Tax additional duties

(3) Excise Duty levied under the Medicinal and Toiletries Preparation Act

(4) Countervailing Duty (CVD), i.e., Additional customs Duty

\subsubsection{State Taxes Which will Get Subsumed Under GST}

(1) Luxury Tax

(2) Entertainment Tax (unless it is levied by the Local bodies)

(3) State VAT/Sales Tax

(4) Taxes on lottery, betting and gambling

(5) State Cess and Surcharges in so far as they relate to supply of goods and services

(6) Entry Tax

(7) Central state tax

\section{Applicability of the Goods and Services Tax on the Basis of Turnover}

(1) The newly constituted Council decided to keep the revenue exemption limit at Rs. 20lakh for all states with the exception of north eastern and the hill states where the limit will be Rs. 10lakh ( Uttrakhand, Himachal Pradesh, J\&K, and all eastern states) [7] [4]

(2) States will have exclusive control over all dealers up to a revenue threshold of Rs. 1.5 crore in a year.[6][9]

(3) Central government \& states government both will have control over all dealers having turnover more than 1.5 crore in a year. [7] [6]

\subsection{Features of Proposed Registration - Goods and Services Tax}

The major features of the proposed registration procedures under GST are as follows:

(1) Existing dealers: Existing VAT/Central excise/Service Tax payers will not have to apply a fresh for registration under GST [6].

(2) New dealers: Single application to be filed online for registration under GST [7].

(3) The registration number will be PAN based and will serve the purpose for both Centre and State [6].

(4) There will be Unified application to both tax authorities [4].

(5) Each dealer will be given a unique ID GSTIN [11].

(6) Deemed approval within three days [2].

(7) Post registration verification in risk based cases only [8] [6].

\subsection{Features Related to Proposed Filing for Goods and Services Tax}

The major features of the proposed returns filing procedures under GST are as follows:

(1) Common return would serve the purpose of both Centre and State Government [7] [5]

(2) There are eight forms provided for in the GST business processes for filing for returns. Most of the average tax payers would be using only four forms for filing their returns. These are return for supplies, return for purchases, monthly returns and annual return [5]

(3) Small taxpayers: Small taxpayers who have opted composition scheme shall have to file return on quarterly basis [5] [9] [10] 
(4) Filing of returns shall be completely online. All taxes can also be paid online. Proposed e-filing GST [3] [6] [9]

\subsection{Benefits of Goods and Services Tax}

The following are various benefits available for different types of parties

\subsubsection{Benefits to Consumers}

(1) Single and transparent tax proportionate to the value of goods and services [7] [9]

(2) Due to multiple indirect taxes being levied by the Centre and State, with incomplete or no input tax credits available at progressive stages of value addition, the cost of most goods and services in the country today are laden with many hidden taxes. [2] [4] [8]

(3) Under GST, there would be only one tax from the manufacturer to the consumer, leading to transparency of taxes paid to the final consumer. [6] [8] [10]

(4) Relief in overall tax burden: Because of efficiency gains and prevention of leakages, the overall tax burden on most commodities will come down, which will benefit consumers

\subsubsection{Benefits to Government}

(1) Better controls on leakage: GST will result in better tax compliance due to a robust IT infrastructure. [6] Due to the seamless transfer of input tax credit from one stage to another in the chain of value addition, there is an inbuilt mechanism in the design of GST that would incentivize tax compliance by traders [2].

(2) Simple and easy to administer: Multiple indirect taxes at the Central and State levels are being replaced by GST. [5] [10]Backed with a robust end to end IT system, GST would be simpler and easier to administer than all other indirect taxes of the Centre and State levied so far. [10]

(3) Higher revenue efficiency: GST is expected to decrease the cost of collection of tax revenues of the Government, and will therefore, lead to higher revenue efficiency [6] [8]

Benefits to Industries

(1) Easy compliance: A robust and comprehensive IT system would be the foundation of the GST regime in India. [6] [8] [10] Therefore, all tax payer services such as registrations, returns, payments, etc. would be available to the taxpayers online, Which would make following easy and transparent. [7] [6] [2]

(2) Uniformity of tax rates and structures: GST will ensure that indirect tax rates and structures are common across the country, Thereby increasing certainty and ease of doing business. [3] [6] [9] In other words, GST would make doing business in the country tax neutral, irrespective of the choice of place of doing business. [8] [10]

(3) Removal of cascading: A system of seamless tax credits throughout the value chain, and across boundaries of States, Would ensure that there is minimal cascading of taxes. This would reduce hidden costs of doing business. [1] [9]

(4) Improved competitiveness: [10] Reduction in transaction costs of doing business would eventually lead to an improved competitiveness for the trade and industry.

(5) Gain to manufacturers and exporters: The subsuming of major Central and State taxes in GST, Complete and comprehensive setoff of input goods and services and phasing out of Central Sales Tax (CST) [9] [10]would reduce the cost of locally manufactured goods and services. This will increase the competitiveness of Indian goods and services in the international market

\section{Conclusion}

The country is keenly looking for the roll-out of GST from April 2017, as the government focuses on creating one single tax \& market for all in India. GST in India will make the country industry friendly by implementing one type of tax and that will attract more investments from foreign investors also.

Also, implementation of dual model of GST will result in generating more employment opportunities. Therefore, it is very important that the government makes efforts to make the GST applicable all over the country with clear law and industry friendly so that the industry, consumers and the economy benefits as a whole.

\section{References}

[1] Goods and services tax and its impact, by jaspreet kaur, IJAR, (2016), Vol 2(8), pages: 385-387.

[2] Basic concepts and features of goods and services tax in India, girish garg, vol 2, issue 2, pages: 542-549, (2014).

[3] GST impact in manufacturing sector, by SKP.

[4] A study on impact of GST after its implementation, vol 1, issue 2 , nov 2016.

[5] Gupta, A., (Sep., 2016), "Goods \& Service Tax-A Game changer in 21 st Century", The Chartered Accountant Student, ICAI, Vol.-30, No.-4, 11-18.

[6] Goods and service tax (GST) in India - Challenges Ahead, February 28, 2016.

[7] GST in india: a key tax reform, IJRG Dec 2016, vol 3, issue: 12, pages: $133-141$.

[8] A research paper on an impact of goods and services tax (GST) on Indian Economy, business and Economics journal, Dani bus, j 2016, 7: 4.

[9] Goods and services tax in india, taking stock and setting expectations, by Deloitte, Assocham india, D. S. rawat.

[10] Does goods and service tax leads to Indian economic development, vol17, dec2015, pp01-05, ISOR.

[11] The impact of GST on the Indian tax scene, kiit university, $1^{\text {st }}$ sep, atul patel, aurobinda panda. 